Proceedings

\title{
Improving the Monitoring System Towards Early Detection and Prediction of the Siberian Moth Outbreaks in Eastern Siberia ${ }^{\dagger}$
}

\author{
Svetlana M. Sultson 1, Andrey A. Goroshko ${ }^{1}$, Pavel V. Mikhaylov 1,*, Denis A. Demidko ${ }^{1,2}$, Evgenii Ponomarev ${ }^{1,2}$ \\ and Sergey V. Verkhovets ${ }^{1}$
}

Citation: Sultson, S.M.; Goroshko, A.A.; Mikhaylov, P.V.; Demidko, D.A.; Ponomarev, E.; Verkhovets, S.V. Improving the Monitoring System Towards Early Detection and Prediction of the Siberian Moth Outbreaks in Eastern Siberia, in Proceedings of the 1st International Electronic Conference on Entomology, 1-15 July 2021, MDPI: Basel, Switzerland, doi:10.3390/IECE-10403

Published: 30 June 2021

Publisher's Note: MDPI stays neutral with regard to jurisdictional claims in published maps and institutional affiliations.

Copyright: (c) 2021by the authors. Submitted for possible open access publication under the terms and conditions of the Creative Commons Attribution (CC BY) license (https://creativecommons.org/license s/by/4.0/).
1 Reshetnev Siberian State University of Science and Technology, 31, Krasnoyarskii Rabochii prospekt, Krasnoyarsk, 660037, Russian Federation, sultson2011@yandex.ru (S.M.S.); utrom3@gmail.com (A.A.G.); mihaylov.p.v@mail.ru (P.V.M.); sawer-beetle@yandex.ru (D.A.D.); evg@ksc.krasn.ru (E.P.); sverhovec@gmail.com (S.V.V.)

2 Sukachev Institute of Forest, Siberian Branch, Russian Academy of Science, 50, bil. 28, Akademgorodok, Krasnoyarsk, 660036, Russia

* Correspondence: mihaylov.p.v@mail.ru (P.V.M.)

+ Presented at the 1st International Electronic Conference on Entomology (IECE 2021), 1-15 July 2021; Available online: https://iece.sciforum.net/.

\begin{abstract}
The Siberian moth, Dendrolimus sibiricus Tschetverikov (Lepidoptera: Lasiocampidae) is a dangerous pest of the taiga forest in Siberia. The present research is aimed to improve the monitoring system towards early detection and prediction of the Siberian moth outbreaks in dark-coniferous taiga in the mountainous region of Krasnoyarsk Krai (Eastern Siberia). The study determined the habitats preferred by the Siberian moth considering the relief, the type of forest and forest inventory characteristics. For that, we analyzed data obtained with the remote sensing and those collected in nature in 2018-2019 through surveying the plots damaged by the pest.
\end{abstract}

Keywords: coniferous pest, dark coniferous stands, serve defoliation, forest type, survey, prediction

\section{Introduction}

The Siberian moth, Dendrolimus sibiricus Tschetverikov (Lepidoptera: Lasiocampidae) is a serious pest of the taiga forest in Siberia [1-4]. It has already destroyed vast forests predominated by fir Abies sibirica, spruce Picea abies and five-needle pine Pinus sibirica (socalled dark-coniferous taiga). Evergreen trees cannot withstand severe defoliation and die $[5,6]$. Climate change may promote the pest outbreaks resulting in significant ecological and economical losses in Siberia [7].

We aim to improve the monitoring system towards early detection and prediction of the Siberian moth outbreaks in dark-coniferous taiga in the mountainous region of Krasnoyarsk Krai (Eastern Siberia). The first step is to determine the habitats with the optimal conditions for the pest development and foci occurrence.

For that, we analyzed data obtained with the remote sensing and those collected in nature in 2018-2019 through surveying the plots damaged by the pest. To define the habitats with the optimal conditions, we took into account the relief, the type of forest and forest inventory characteristics. Figure 1 demonstrates the study area in September 9, 2019.

There were six forest types in the damaged area: Bergenia, Reedgrass/Tall Grasses, Bilberry, Mossy, Sedges/Herb-rich, and Next-to-the-stream. Figure 2 shows the spatial distribution of forest types within the study area.

The study area is located in mid-mountain relief. Most of forest types are located on neutrally-insolated slopes (Figure 3). 


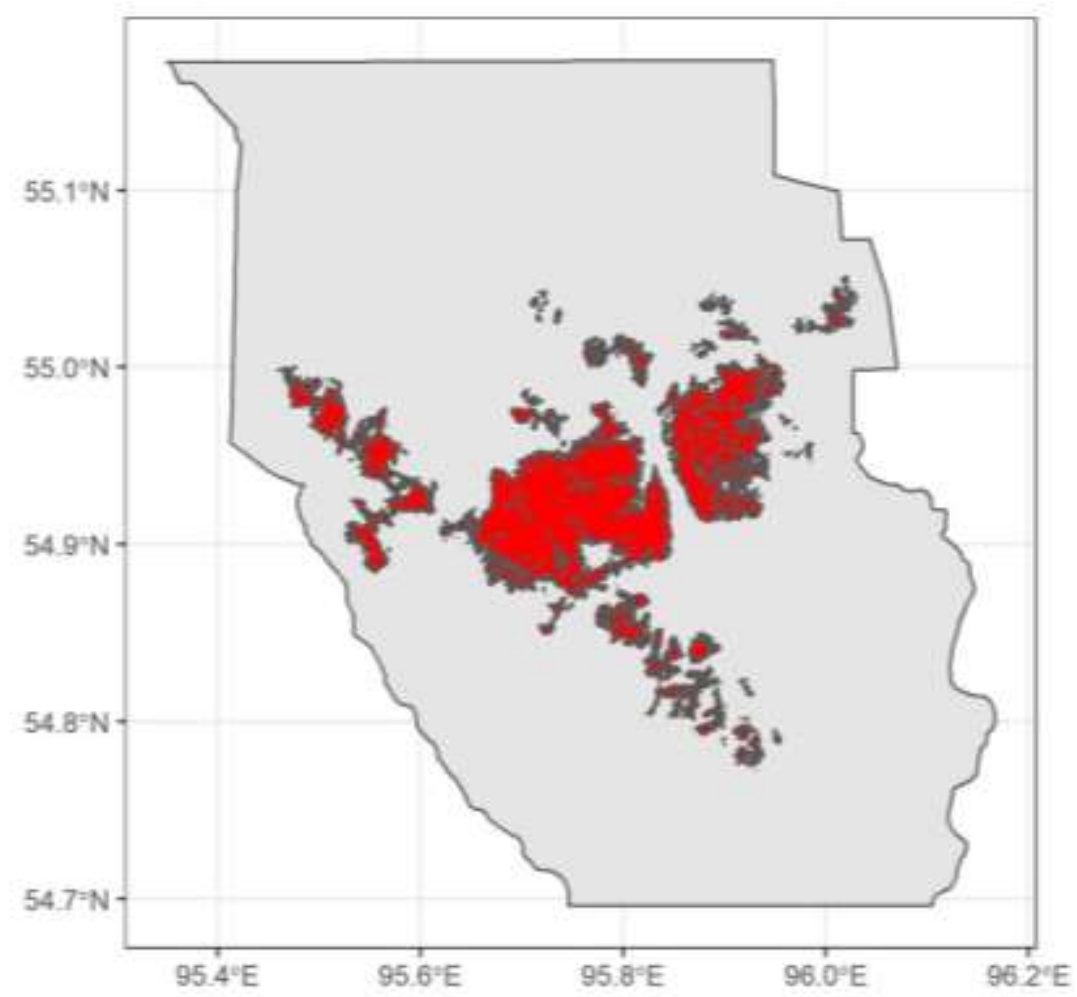

Figure 1. Study area of dark-coniferous taiga damaged by the Siberian moth (Eastern Siberia, Krasnoyarsk Krai, South Siberia Mountain Forest Zone, Altay-Sayan Mountain Taiga Province. Red shows the areas of forest stands damaged by the pest (defoliation of $50 \%$ or more) on a 09.09.2019.

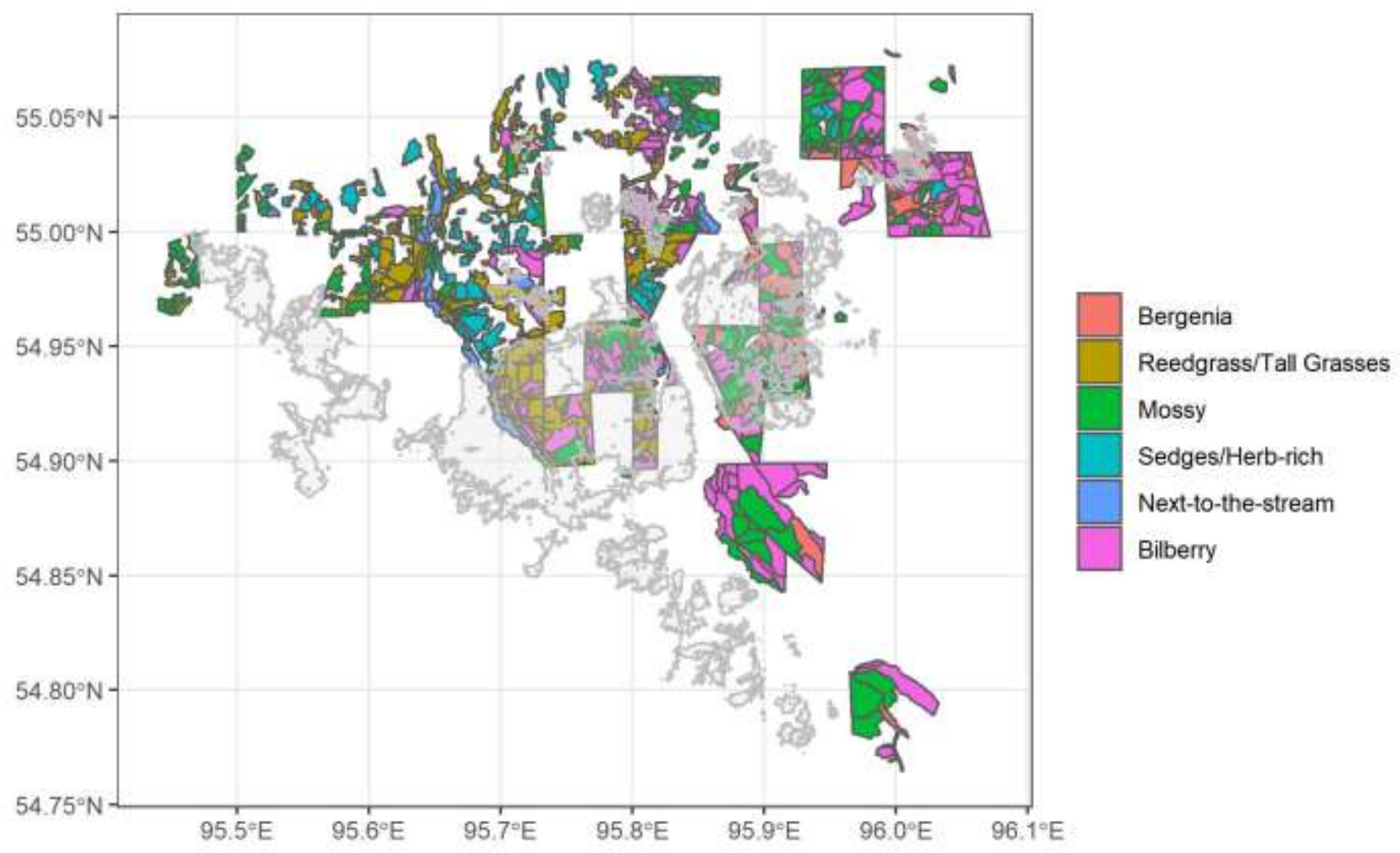

Figure 2. Spatial distribution of forest types within the damaged dark-coniferous stands. 


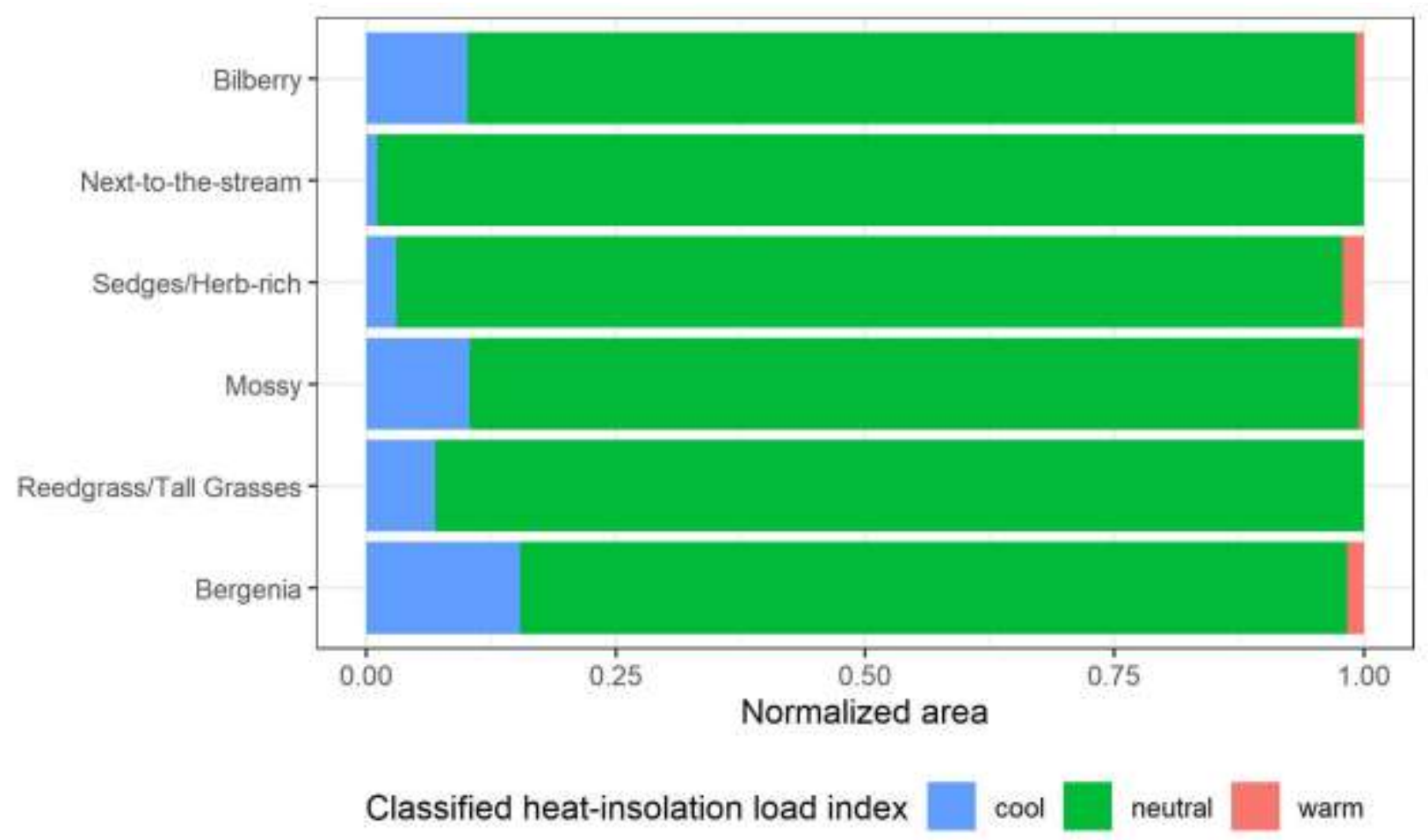

Figure 3. Stands distribution by forest types depending on solar radiation on sloping surfaces.

The analysis did not reveal a significant correlation between insolation on slopes and forest type in areas defoliated by the Siberian moth neither at the onset nor during an outbreak.

Figure 4 shows indicators for quantifying the Siberian moth larvae abundance according to the field study where forest type and tree species were took into account. At the time of survey (September, 2019) larvae of the third and forth instars dominated in the age structure of the population. We found no larvae being ill or infested with parasites.

The most preferred habitats of $D$. sibiricus, where its foci most often occur, are mossy insolated forest plots, followed by grassy forest plots. The plots situated in the terrain depressions, next to the streams, as well as grassy-bog forests are avoided by the pest. We showed that population density of the pest depends on the forest structure.

We indicated that larvae population size increased when Pinus sibirica and Abies sibirica dominated in the stand structure. The revealed pattern in pests' distribution is determined by the Siberian moth preferred host-trees (Figure 5).

The indicators for larvae abundance were higher in mid-density forest stands (a relative density of $0.5-0.7$ ). The Siberian moth population density was low in stands with a relative density of 0.4 and 0.9 (Figure 6).

As a result, we differentiated forest stands by the degree of their resistance to the insect attacks. The obtained results can be used for improving the pest monitoring and the prediction of its outbreaks. 


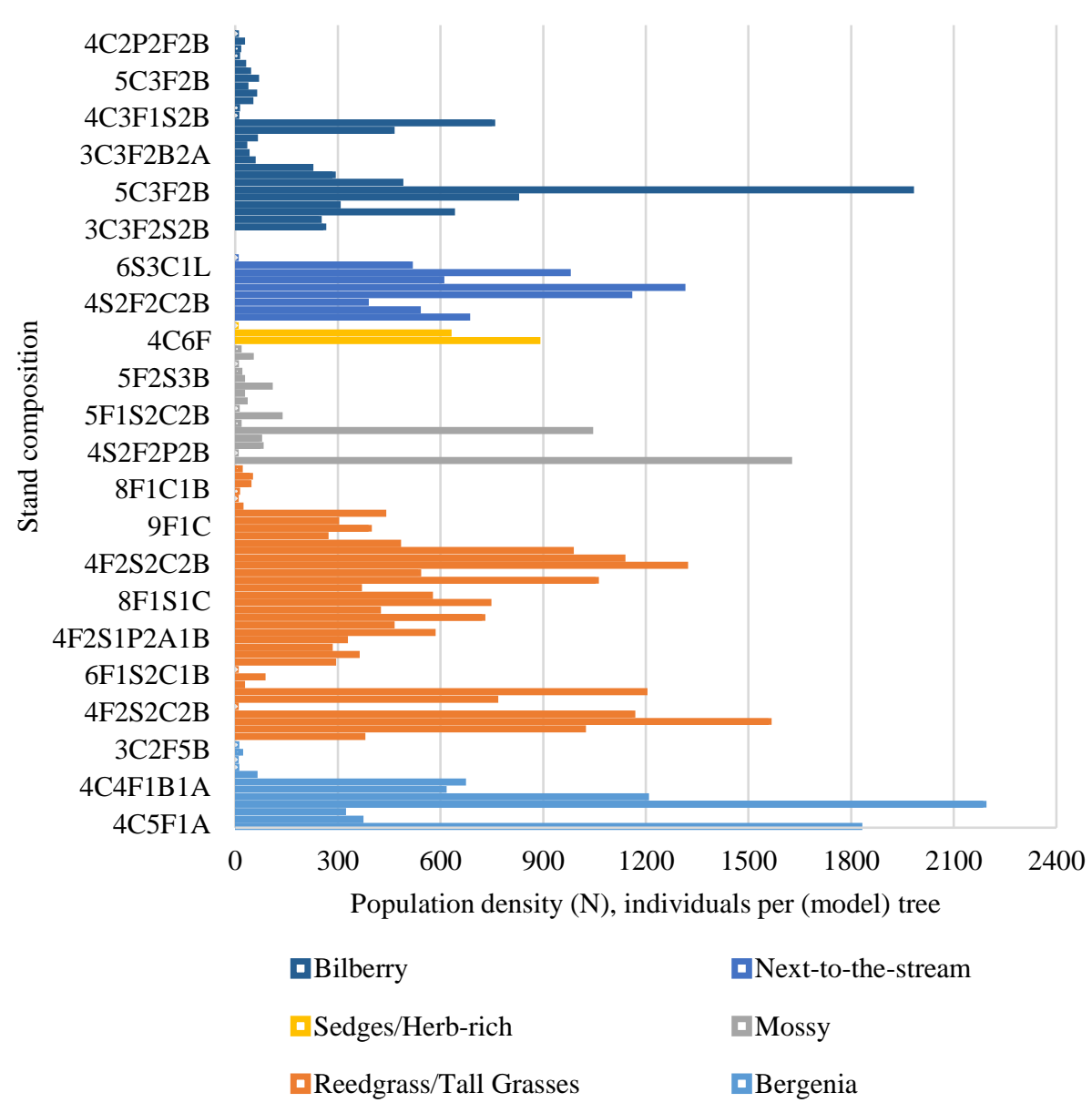

Figure 4. The Siberian moth population density $(\mathrm{N})$ depending on forest type and stand species composition: tree species - Siberian pine (C) (Pinus sibirica), Pine (P) (Pinus sylvestris), Fir (F) (Abies sibirica), Spruce (S) (Picea obovata), Larch (L) (Larix sibirica), Birch (B) (Betula pendula), Aspen (A) (Populus tremula); 1,2, 3...8,9-numbers show the share of the species in the total timber stock (e.g. $2=20 \%$ ).

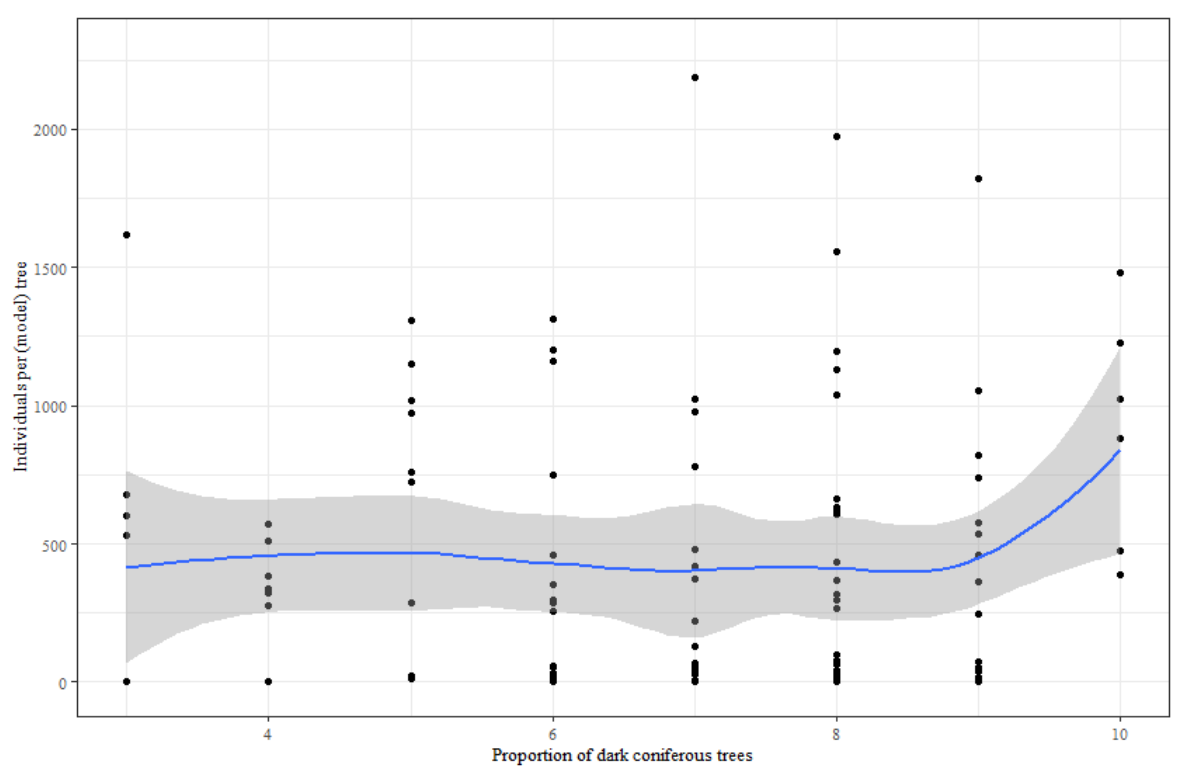

Figure 5.Correlation between the Siberian moth abundance and the proportion of dark-coniferous species (Pinus sibirica and Abies sibirica) in the stand species composition. 


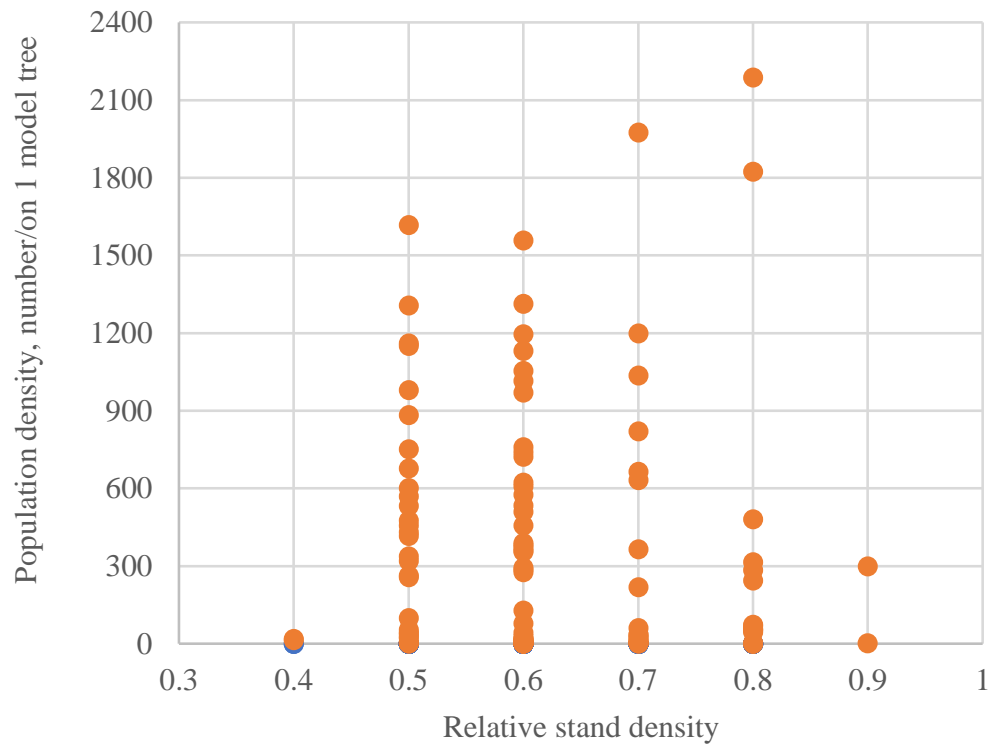

Figure 6. Correlation between the relative density of forest stands and the Siberian moth population density.

Funding: The research was carried out within and the State Assignment (theme «Fundamental principles of forest protection from entomo- and phyto- pests in Siberia» No. FEFE-2020-0014) supported by the Ministry of Education and Science of the Russian Federation.

Institutional Review Board Statement: Not applicable.

Informed Consent Statement: Not applicable.

Conflicts of Interest: The authors declare no conflict of interest. The funders had no role in the design of the study; in the collection, analyses, or interpretation of data; in the writing of the manuscript; or in the decision to publish the results.

\section{References}

1. Isaev, A.S.; Palnikova, E.N.; Sukhovolsky, V.G.; Tarasova, O.V. Population dynamics of defoliating forest insects: models and forecasts, Moscow: KMK Scientific Press Ltd., Russia, 2015, 262 p.

2. Rozhkov, A.S. Outbreaks of Siberian silk moth and measures of their control, Moscow: Nauka, Russia, 1965, 179 p.

3. Kirichenko, N.I.; Baranchikov, Y.N.; Vidal, S. Performance of the potentially invasive Siberian moth Dendrolimus superans sibiricus on coniferous species in Europe. Agric. For. Entomol.2009, 11, 247-254.

4. Kharuk, V.I.; Demidko, D.A.; Fedotova, E.V.; Dvinskaya, M.L.; Budnik, U.A. Spatial and temporal dynamics of Siberian silk moth large-scale outbreak in dark-needle coniferous tree stands in Altai. Contemp. Probl. Ecol.2016, 9, 711-720.

5. Bakhvalov, S.A.; Koltunov, E.V.; Martemyanov. V.V Factors and ecological mechanisms of population dynamics of forest insects-folivores. Novosibirsk: Publisher of Siberian Branch of Russian Academy of Science, Russia, 2010, 229 p.

6. Zhirin, V.M.; Knyazeva, S.V.; Eydlina, S.P. Long-term dynamics of vegetation indices in dark coniferous forest after Siberian moth disturbance. Contemp. Probl. Ecol.,2016, 9, 834-843.

7. Kharuk, V.I.; Im, S.T.; Soldatov, V.V. Siberian silkmoth outbreaks surpassed geoclimatic barrier in Siberian Mountains. J. Mt. Sci.,2020, 17, 1891-1900. 